\title{
Hypopharyngeal Cancer pN3 TNM Finding v7
}

National Cancer Institute

\section{Source}

National Cancer Institute. Hypopharyngeal Cancer pN3 TNM Finding v7. NCI Thesaurus.

Code $C 89039$.

Hypopharyngeal cancer with metastasis in a lymph node more than $6 \mathrm{~cm}$ in greatest

dimension. (from AJCC 7th Ed.) 